\title{
Performance of NPK with Vermicompost and Boron on Growth and Quality Attributes of Brinjal (Solanum melongena L.)
}

\author{
Bhagchand Yadav*, A. K. Soni, Suman Yadav, Mahendra Yadav and G. L. Yadav \\ Department of Horticulture, S.K.N. College of Agriculture, Jobner-303328, India \\ S.K.N. Agriculture University, Jobner, Jaipur, Rajasthan, India \\ *Corresponding author
}

A B S T R A C T

\begin{tabular}{|l|}
\hline Ke y w o r d s \\
NPK, Boron, \\
Vermicompost, \\
Quality, Growth \\
and Brinjal
\end{tabular}

A field experiment was conducted to study "Performance of NPK with Vermicompost \& Boron on Growth and Quality attributes of Brinjal (Solanum melongena L.)" during rainy season 2017-18 at Horticulture Farm, S.K.N. College of Agriculture, Jobner (Jaipur). The total 18 treatment combinations were tested in randomized block design with three replications. The application of 50\% NPK $+50 \%$ VC significantly increased chlorophyll content $(\mathrm{mg} / \mathrm{g})$, number of primary branches plant ${ }^{-1}$, leaf area $\left(\mathrm{cm}^{2}\right), \mathrm{K}$ content in fruit $(\%)$, boron $(\mathrm{mg} / 100 \mathrm{~g})$ and ascorbic acid content in fruit $(\mathrm{mg} / 100 \mathrm{~g})$, as compared to control but statistically at par with $25 \%$ NPK $+75 \%$ VC. The application of boron (200 ppm) significantly increased the number of primary branches plant ${ }^{-1}$, leaf area $\left(\mathrm{cm}^{2}\right), \mathrm{K}$ content in fruit (\%), boron and ascorbic acid content in fruit $(\mathrm{mg} / 100 \mathrm{~g})$, as compared to control and boron (100 ppm).

\section{Introduction}

Brinjal (Solanum melongena L.) is also known as egg plant or aubergine. The green leaves of plant are the main source of the supply of antiascorbic acid (vitamin- C). It is used in Ayurveda as appetizer, "cardiotonic" and aphrodisiac and fruit exhibits laxative property and provides relief from inflammation. It has got much potential as raw material in pickle making and dehydration industry. The white brinjal is said to be good for diabetic patients. It can also cure toothache and liver complains (Chouhan, 1981). Brinjal is also used for the treatment of bronchitis, asthma, dysentery, etc. it is also helpful for decreasing the level of blood cholesterol. Brinjal is low in energy (30 $\mathrm{kcal} / 100 \mathrm{~g})$, protein $(1.4 \%)$ and vitamin $\mathrm{C}$ $(5 \mathrm{mg} / 100 \mathrm{~g})$, but is a very good source of dietary fiber, potassium, calcium, manganese, copper and vitamin A and B also possess antioxidant ability (Anonymous, 2012). The 
yield potential and quality of fruits could be improved by maintaining proper fertilizer appliance. Nitrogen is considered as building stone in the manufacture of protein and chief ingredient of protoplasm. Increasing the nitrogen significantly delayed flowering of eggplant and increased the number of days taken to fruit setting of eggplant (Sat and Saimbhi, 2003). Among the nutrients essential for the crop, nitrogen is found to be deficient in most of the Indian soil (Arakeri et al., 1956). Phosphorus participates in the skeleton of plasma membrane, nucleic acids, many coenzymes, organic molecules and other phosphorylated products, carbohydrates synthesis and nutrient contents like $\mathrm{Ca}, \mathrm{Mg}, \mathrm{N}$, $\mathrm{K}$ and S (Badiger et al., 2006), which are of great importance in the transformation of energy within the plant system. Potassium increased vigour and disease resistance to plant, it also regulates water condition within the plant cell and water loss from the plant by maintaining the balance between anabolism, respiration and transpiration. Potassium activates the fat producing enzymes and enhances the oil content (Mandal and Chatterjee, 1973). Application of N.P.K. through inorganic fertilizer can enhances the growth and quality to a considerable extent but soil fertility and productivity cannot be retained for longer period. Therefore, it is important to supplement the recommended fertilizers. The integrated nutrient management helps to restore and sustain fertility and crop productivity. The use of vermicompost has been advocated in integrated nutrient management (INM) system in vegetable crops. Its uses as a resource of organic manure in supplementing chemical fertilizer is becoming popular among the farmers of the country, increase in crop yield and nutrient uptake was reported by Bhawalkar and Bhawalkar, 1993 due to relevance of Vermicompost. Vermicompost is also useful as it increases soil porosity, aeration and water holding capacity. The advantage of integrated use of inorganic and organic sources generally superior over use of each component individually (Saravaiya et al., 2010). Micronutrients such as boron had great influence on plant growth and development. Boron deficiency caused delay in pollen germination and pollen tube development and ultimately it halts flowering and fruit setting (Halfacre and Barden, 1979). Boron deficiency may cause sterility i.e less fruits per plant attributing lower yield (Islam and Anwar, 1994). This emphasizes the need for a judicial use of B fertilizer. Keeping this in view, the present investigation was planned to study the performance of NPK with vermicompost \& boron on growth and quality attributes of brinjal (Solanum melongena L.)

\section{Materials and Methods}

A field experiment to study the "Performance of NPK with Vermicompost \& Boron on Growth and Quality attributes of Brinjal (Solanum melongena L.)" was conducted at Horticulture farm, Department of Horticulture, S.K.N. College of Agriculture, Jobner (Jaipur) during July to December 2017-18. The climate of this region is typically semi-arid, characterized by extremes of temperatures during both summer and winter. During summer, the temperature may go as high as $48^{\circ} \mathrm{C}$ while in winters, it may fall as low as$1^{0} \mathrm{C}$. The long term average annual rainfall of the region ranges between $400-500 \mathrm{~mm}$, most of which is received in July and August but the amount has declined over the recent years. The details of the experimental techniques, material used and criteria adopted for the assessment of treatments during the course of investigation are being presented in this paper. The soil of the experimental field was loamy sand in texture, slightly alkaline in reaction, poor in organic carbon, low available nitrogen (135.05 $\left.\mathrm{kg} \mathrm{ha}^{-1}\right)$, phosphorus (16.67 $\mathrm{kg} \mathrm{ha}^{-1}$ ) and medium in potassium content $(150.83 \mathrm{~kg}$ $\left.\mathrm{ha}^{-1}\right)$. 18 treatments combination which 
consisted of six levels of INM \& Vermicompost $\left(\mathrm{N}_{0}=\right.$ Control, $\mathrm{N}_{1}=100$ per cent RD of NPK through inorganic fertilizers, $\mathrm{N}_{2}=75$ per cent RD of NPK through inorganic fertilizers +25 per cent through $\mathrm{VC}, \mathrm{N}_{3}=50$ per cent RD of NPK through inorganic fertilizers +50 per cent through $\mathrm{VC}, \mathrm{N}_{4}=25$ per cent RD of NPK through inorganic fertilizers +75 per cent through $\mathrm{VC}, \mathrm{N}_{5}=100 \%$ $\mathrm{RD}$ of NPK through vermicompost) and three levels of Boron $\left(B_{0}=\right.$ Control, $B_{1}=100 \mathrm{ppm}$, $\left.\mathrm{B}_{2}=200 \mathrm{ppm}\right)$ were replicated three times. The experiment was laid out in a Randomized Block Design (RBD) with 18 treatments combination. Thirty days old seedlings of Pant Rituraj variety were transplanted at the spacing of $60 \mathrm{~cm} \times 45 \mathrm{~cm}$ in Kharif, 2017-18. Harvesting was done during month of January 2018. Data were collected from five randomly selected plants for each plot and the recorded parameters were Number of primary branches, Leaf area $\left(\mathrm{cm}^{2}\right)$, Potassium content in fruit $(\%)$, Ascorbic acid content in fruit (mg/100 g), Boron content in fruit $(\mathrm{mg} / 100 \mathrm{~g})$.

\section{Results and Discussion}

\section{Number of primary branches}

The result showed that the application of $\mathrm{N}_{3}$ treatments $(50 \%$ NPK $+50 \%$ VC) significantly increase the number of primary branches (7.64) rather than control $\left(\mathrm{N}_{0}\right)$ and at par with $\mathrm{N}_{4}(25 \% \mathrm{NPK}+75 \% \mathrm{VC})$ treatment (9.46). The number of primary branches under the treatment $\mathrm{N}_{3}(50 \% \mathrm{NPK}+50 \% \mathrm{VC})$ was found 25.19 per cent more as compared to control. This might be due to the better nutritional environment in the root zone for growth and development of the plant by the application of NPK with vermicompost (Abusaleha and Shanmulagavelu, 1988).

The effect of vermicompost on physicochemical properties imparts favourable soil structure for root growth which influenced better plant growth. These results are in conformity with findings of Anburani and Manivannan, (2002) in brinjal, Kumar et al., (2013) in tomato, Vitakar et al., (2007) in chilli. The increasing levels of boron also significantly increased the number of primary branches (9.41) in treatment $\mathrm{B}_{2}(200 \mathrm{ppm})$ and minimum (8.32) was observed under control. The number of primary branches under the treatment $\mathrm{B}_{2}(200 \mathrm{ppm})$ was recorded 13.10 per cent more than control. Number of leaves increased may be due to promotive effects of macro and micronutrients on vegetative growth which ultimately lead to more photosynthetic activities. The findings is also in agreement with the findings of Das and sahoo in potato, (1975), Basavarajeswari et al., in tomato, (2008), Patil et al., in tomato, (2008), Dubey et al., in bellpeper (2013).

\section{Leaf area}

The application of treatment $\mathrm{N}_{3}(50 \% \mathrm{NPK}+$ $50 \%$ VC) was found maximum leaf area $\left(2341.49 \mathrm{~cm}^{2}\right)$, which was statistically at par with application of treatment $\mathrm{N}_{4}(25 \% \mathrm{NPK}+$ $75 \%$ VC). Whereas, minimum leaf area $\left(1907.76 \mathrm{~cm}^{2}\right)$ was observed under control.

The leaf area under the treatment $\mathrm{N}_{3}(50 \%$ $\mathrm{NPK}+50 \% \mathrm{VC}$ ) was found 22.73 per cent more as compared to control. The NPK are considered as one of the major nutrients required for proper growth and development of the plant. These results are in conformity with findings of Rao and Sankar, (2001) in brinjal, Arancon et al., (2003) in pepper. The application of boron at $\mathrm{B}_{1}(100 \mathrm{ppm})$ and $\mathrm{B}_{2}$ (200 ppm) were found significantly superior to control. The maximum Leaf area (2263.69 $\mathrm{cm}^{2}$ ) was recorded in treatment $\mathrm{B}_{2}(200 \mathrm{ppm})$. However it was found minimum (2061.54 $\mathrm{cm}^{2}$ ) under control. Application of treatment $\mathrm{B}_{2}(200 \mathrm{ppm})$ registered an increase of 9.80 percent higher leaf area over control. 
Table.1Effect of NPK with vermicompost and boron on Number of primary branches, Leaf area $\left(\mathrm{cm}^{2}\right)$, Potassium content in (\%), ascorbic acid $(\mathrm{mg} / 100 \mathrm{~g})$ and boron content $(\mathrm{mg} / 100 \mathrm{~g})$ of brinjal fruits.

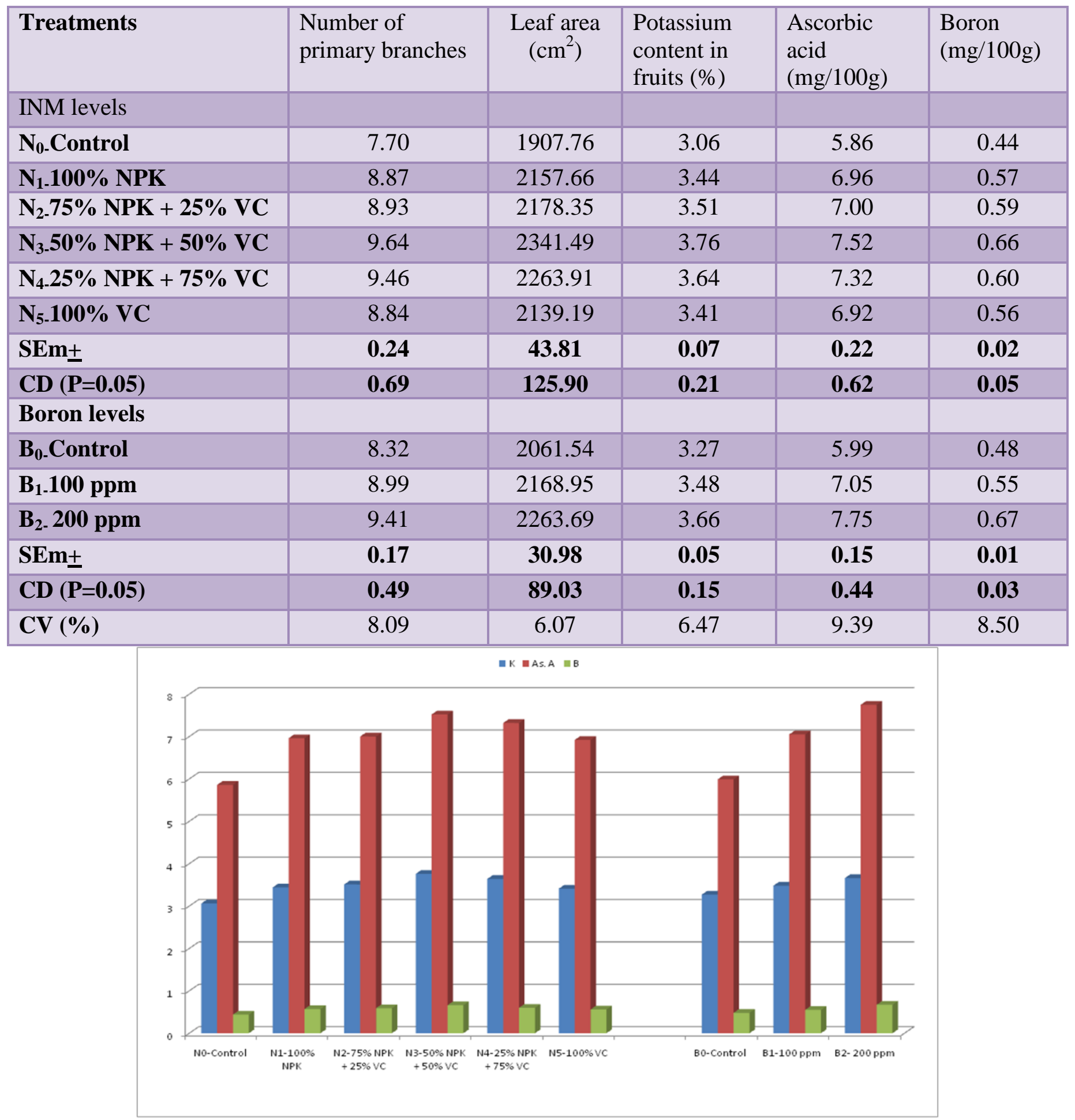

Fig. 1 Effect of NPK with vermicompost and boron on K, Ascorbic acid and Borom content in fruit of brinjal 
Foliar sprays of Boron increased the nitrogen content of the leaves. Leaf area index was significantly increased by nitrogen, possibly because nitrogen helps in greater assimilation of food material by the plant which resulted in greater meristematic activities of cells and consequently the number of leaves, length and width of leaf of plant. The findings is also in agreement with the findings of Solanki et al., in brinjal, (2017), Patil et al., in tomato, (2008).

\section{Potassium content in fruit}

The maximum potassium content in fruit (3.76 $\%$ ) was observed under the treatment $\mathrm{N}_{3}(50 \%$ $\mathrm{NPK}+50 \% \mathrm{VC})$, followed by $\mathrm{N}_{4}(25 \% \mathrm{NPK}$ $+75 \% \mathrm{VC})$. Whereas, minimum potassium content $(3.06 \%)$ was observed under control.

These results are also in close conformity with the finding of Choudhary et al., (2007) in brinjal, Anwar et al., (2017) in tomato and significantly maximum potassium content in fruit $(3.66 \%)$ was recorded in treatment $\mathrm{B}_{2}$ (200 ppm), and minimum (3.27 \%) was observed under control.

The per cent increase potassium content in fruit under the treatment $B_{2}(200 \mathrm{ppm})$ was found to be 11.92 per cent over control. Similar quality parameters were also reported by Selvi et al., (2004) and Salam et al., (2011).

\section{Ascorbic acid content in fruit}

The maximum ascorbic acid content in fruit (7.52 $\mathrm{mg} / 100 \mathrm{~g})$ was observed under the treatment $50 \% \mathrm{NPK}+50 \% \mathrm{VC}\left(\mathrm{N}_{3}\right)$, which was statistically at par with treatment $\mathrm{N}_{4}(25 \%$ $\mathrm{NPK}+75 \%$ VC). Whereas, minimum ascorbic acid content in fruit $(5.86 \mathrm{mg} / 100 \mathrm{~g})$ was observed under control $\left(\mathrm{N}_{0}\right)$. The per cent increase ascorbic acid content in fruit under the treatment $\mathrm{N}_{3}(50 \% \mathrm{NPK}+50 \% \mathrm{VC})$ was found to be 28.32 per cent over control. These results are also in close conformity with the finding of Chumei et al., (2014) in brinjal, Laxmi et al., (2015) in tomato, Anwar et al., (2017) in tomato. Boron also had significant effect on ascorbic acid content in fruit as compared to control. The maximum ascorbic acid content in fruit $(7.75 \mathrm{mg} / 100 \mathrm{~g})$ was recorded under treatment $\mathrm{B}_{2}(200 \mathrm{ppm})$, and minimum $(5.99 \mathrm{mg} / 100 \mathrm{~g})$ was observed under control. Similar quality parameters were also reported by Selvi et al., (2004) in brinjal and Salam et al., (2011) in tomato, Singh et al., (2014) in chilli.

\section{Boron content in fruit}

The maximum boron content in fruit $(0.64$ $\mathrm{mg} / 100 \mathrm{~g}$ ) was observed under the treatment $\mathrm{N}_{3}(50 \%$ NPK $+50 \% \mathrm{VC})$, which was statistically at par with application of treatment $\mathrm{N}_{4}(25 \% \mathrm{NPK}+75 \% \mathrm{VC})$. While is was minimum boron content in fruit $(0.44$ $\mathrm{mg} / 100 \mathrm{~g}$ ) were observed under control. These results are also in close conformity with the finding of Selvi et al., (2004) in brinjal. There was a significant influence on boron content in fruit as compared to control. The maximum boron content in fruit $(0.67 \mathrm{mg} / 100 \mathrm{~g})$ was recorded in treatment $B_{2}(200 \mathrm{ppm})$, and minimum $(0.48 \mathrm{mg} / 100 \mathrm{~g})$ was observed under control. Similar quality parameters were also reported by Singaram and Prabha (1999) in tomato, Salam et al., (2011) in tomato.

On the basis of experimental results, it may be concluded that the application of $50 \%$ NPK + $50 \% \mathrm{VC}$ and $200 \mathrm{ppm}$ boron was found significantly better in terms of growth, and quality compared to other treatment. Thus, application of $50 \% \mathrm{NPK}+50 \% \mathrm{VC}$ or 200 ppm boron are recommended for improve the growth and quality of brinjal.

\section{References}

Abusaleha and Shanmulagavelu, K.G., 1988. Studies on the effect of organic and inorganic source of nitrogen on 
growth, yield and quality of okra (Abelmoschus esculentus). Indian Journal of Horticulture. 45 (3-4): 312318.

Anburani, A. and Manivannan, K., 2002. Effect of integrated nutrient management on growth in brinjal (Solanum melongena L.) $c v$. Annamalai. South Indian Horticulture. 50 (4-6) : 377-386.

Anonymous, 2012. KAU-Agri.Infotech portal http://www.celkau.in/Crop /Vegetables / Brinjal/ brinjal.aspx (Accessed on 08.08.2014).

Anwar, A.K., Hamida, B., Zahid A., Muhammad, S., Syed, A.S., Haroon, I., Kashif, K., Imran A. and Sajid A., 2017. Effect of compost and inorganic fertilizers on yield and quality of tomato. Academia Journal of Agricultural Research. 5 (10) : 287293.

Arakeri, H.R., Chalam, G.U., Satyanarayan, P. and Dona-hae, R.L., 1956. Soil Management in India.Asian Publication House, Bombay.

Arancon, N.Q., Edwards, C.A., Bierman, P. and Metzger., 2003. Effect of vermicompost on growth and marketable fruits grown tomatoes, peppers and strawberries. $7^{\text {th }}$ International Syposium on Earthworm Ecology, Cardiff, Wales, Pedobiologia. 47 (5-6) : 731-735.

Badiger, M.K., Subbareddy, N.P., Roselind M. and Shivaraj, B., 2006. Influence of phosphorus fertilizer on the yield and quality attributes of tomato. Journal of the Indian Society of Soil Science. 43 : 123-129.

Basavarajeswari, C.P., Hosamni R.M., Ajjappalavara, P.S., Naik, B.H., Smitha, R.P. and Ukkund, 2008. Effect of foliar application of micronutrients on growth, yield components of Tomato (Lycopersicon esculentum
Mill). Karnataka Journal Agrcultural Science. 21 (3) : 428-430.

Bhawalkar, U.S. and Bhawalkar, U.V., 1993. Vermiculture Biotechnology In: Organics in Soil Health and Crop Production. P.K.Thapman (ad.), Peekay Tree crops Development Foundation, Cochin. 69-85.

Choudhary, M., Soni, A.K. and Jat, R.G., (2007) Effect of organic and inorganic source of nutrients on quality of brinjal (Solanum melongena L.) cv. Pusa Uttam. Haryana Journal of Horticultural Sciences. 36 (1\&2) : 118119.

Chouhan, D.V.S., 1981. Vegetable Production in India $\left(3^{\text {rd } E d n .) . ~ R a m p r a s a d . ~ a n d ~}\right.$ Sons. Agra, India. 150-158.

Chumei, Kanaujia S.P. and Singh, V.B., 2014. Integrated nutrient management in brinjal Progressive Agriculture. 13 (1) : 106-113.

Das, R.C. and Sahoo, K.C., 1975. Foliar treatments of nutrition on potato (Solanum tuberosum L.) variety Kufri Sindhuri. Research Journal of Orissa University of Agrcultural. and Technology. 5 (1-2) : 96-103.

Dubey, G.D., Parmar, A.S., Kanwer, H.S., Verma, S.C. and Mehta, D.K., 2013. Effect of micronutrients on plant growth and fruit yield parameters of bell pepper (Capsicum annuum L.) grown under mid hill conditions of Himachal Pradesh. Vegetable Science. 40 (1) : 107-108.

Halfacre, R. G. and Barden, J.A., 1979. In: Horticulture, McGraw Hill Book.Co. USA.

Islam, M. S. and Anwar, M. N., 1994. Production technologies of vegetable crops. Recommendation and Future plan. In proceedings of workshop on transfer of technology of CDP crops under Research Extension linkage programme, BARI, Gazipur. pp. 20- 
27.

Kumar, M., Meena, M.L., Kumar, S. and Kumar, D., 2013. Effect of nitrogen, phosphorus and potassium fertilizers on the growth, yield and quality of tomato var. Azad T-6. The Asian Journal of Horticulture. 8(2) : 616-619.

Laxmi, P.R., Saravanan, S. and Naik, M.L., 2015. Effect of organic manures and inorganic fertilizers on plant growth, yield, fruit quality and shelf life of tomato (Solanum lycopersicon L.) c.v. PKM-1. International Journal of Agricultural Science and Research, 5 (2) : 7-12.

Parihar, S.S. and Tripathi, R.S., 2003. Dry matter nodulation and nutrient uptake in potato as influenced by irrigation and Phosphorus. Experimental Agriculture. 25 (3): 349-355.

Patil, Basavarajeshwari C., Hosamani, R. M., Ajjappalavara, P. S., Naik, B. H., Smitha, R. P. and Ukkund, K. C., 2008. Effect of foliar application of micronutrients on growth and yield components of tomato (Lycopersicon esculentum Mill.). Karnataka Journal Agriculture Science. 21 (3) : 428-430.

Rao, T.S. and Sankar, C.R., 2001. Effect of organic manure on growth and yield of brinjal. South Indian Horticultural. 49 : 288-291.

Salam, M. A., Siddique, M. A., Rahim M. A., Rahman M. A. and Goffar, M. A., 2011. Quality of tomato as influenced by boron and zinc in presence of different doses of cowdung. Bangladesh Journal of Agricultural
Research. 36 (1) : 151-163.

Sat, P. and Saimbhi, M.S., 2003. Effect of varying levels of nitrogen and phosphorus on earliness and yield of brinjal hybrids. Journal Reasearch Crops. 4 (2) : 217-222.

Selvi, D., Thiageshwari, S., Santhy, P. and Kannan, B.R., 2004. Fruit yield and nutrient uptake by brinjal due to integrated nutrient management in an Inceptisol. Journal of Maharashtra Agricultural University. 29 (2) : 220223.

Singh, N.K., Sharma, T.R., Bisen, N.K. and Deshmukh, K.K., 2014. Optimization of quantity of foliar spray of boron and zinc in chilli for Kymore plateau and Satpura hills of Madhya Pradesh. Vegetable Science. 41 (1) : 66-67.

Singaram, P. and Prabha, K., 1999. Studies on calcium boron interaction in tomato grown in a calcareous soil. MadrasAgricultural-Journal. 86 (10-12) : 681682.

Solanki, M.M., Solanki, M.S., Thakare, G., Jogi, P.D., and Sapkal, R.D., (2017). Effect of zinc and boron on growth of brinjal (Solanum melongena L.). International Journal of Plant Sciences. 12 (2) : 160-163.

Vitakar, M.N., Manolikar, R.R., Vasmate, S.D., Kalalbandi, B.M. and Patil, M.F., 2007. Effect of organic and inorganic fertilizers on growth and green fruit yield of chilli (Capsicum annum L.). Asian Journal of Horticulture. 2 (2) : 273-276.

\section{How to cite this article:}

Bhagchand Yadav, A. K. Soni, Suman Yadav, Mahendra Yadav and Yadav, G. L. 2019. Performance of NPK with Vermicompost and Boron on Growth and Quality Attributes of Brinjal (Solanum melongena L.). Int.J.Curr.Microbiol.App.Sci. 8(09): 1265-1271. doi: https://doi.org/10.20546/ijcmas.2019.809.141 